\title{
Exposure to dust, endotoxins and microbes in Finnish vegetable greenhouses
}

\author{
Katri Suuronen ${ }^{1, A, C-F \oplus}$, Pirjo Hölttä ${ }^{1, A, E-F \oplus}{ }^{\oplus}$, Mika Korva $^{1, A-C, E-F \oplus}{ }^{\oplus}$ Milja Koponen ${ }^{1, A-F \oplus}$ \\ ${ }^{1}$ Finnish Institute of Occupational Health, Helsinki, Finland \\ A - Research concept and design, B - Collection and/or assembly of data, C - Data analysis and interpretation, \\ $D$ - Writing the article, E - Critical revision of the article, F - Final approval of the article
}

\begin{abstract}
Suuronen K, Hölttä P, Korva M, Koponen M. Exposure to dust, endotoxins and microbes in Finnish vegetable greenhouses. Ann Agric Environ Med. 2022; 29(1): 56-62. doi: 10.26444/aaem/146725
\end{abstract}

\begin{abstract}
Introduction and Objective. In Finland and other northern countries, vegetable greenhouse workers are exposed to airborne dust and microbes all year round. The aim of the study was to assess respiratory exposure to dust, endotoxins and microbes, and to identify the risk phases of respiratory and skin exposure to promote safe working methods.

Materials and method. Work in greenhouses was observed and recorded in a structured form. 23 personal samples and eight stationary samples of dust, endotoxins and viable microbes were collected from eight tomato or cucumber greenhouses in Finland. Dust samples were analysed gravimetrically. Endotoxins were analysed on filters by chromogenic Limulus amoebocyte lysate assay. Microbes were collected on filters, incubated and counted in three different culture media. Eight additional stationary samples of microbes were collected on a six-phase impactor.

Results. The greenhouses were generally clean and well organised, but skin protection was deficient. The median of personal dust exposure was $0.24 \mathrm{mg} / \mathrm{m}^{3}: 0.21 \mathrm{mg} / \mathrm{m}^{3}$ in the tomatohouses and $0.62 \mathrm{mg} / \mathrm{m}^{3}$ in the cucumber greenhouses. The mean level of bacteria in the tomato houses was $2.7 \times 10^{3}$ and in the cucumber houses $1.6 \times 10^{4}$. Those of fungi were $3.6 \times 10^{5}$ and $1.7 \times 10^{5}$ on Hagem and $8.1 \times 10^{5}$ and $1.9 \times 10^{5}$ on DG-18, respectively. The microbes made up about $1 / 10$ of these values in the stationary samples. Very low concentrations of endotoxins were found in 5/23 air samples.

Conclusions. The clean appearance of the greenhouses was reflected in the low to moderate levels of dust. Risk phases of high exposure, such as lifting leaf debris, were identified. The microbe species were typical of this climate, and their levels were comparable to other greenhouse studies, but lower than in farming. Prevention among the foreign workforce is challenging due to the lack of a common language.
\end{abstract}

\section{Key words}

prevention, allergy, bacteria, fungi, agriculture, tomato, cucumber, immigrant, control organism

\section{INTRODUCTION}

During the 2000s, greenhouse cultivation of vegetables has become a fast-growing branch in Finland, as elsewhere, and currently, vegetables are produced on a large scale throughout the year, despite the cold climate. According to the Finnish Glasshouse Growers' Association and the Natural Resources Institute for Finland's statistics, approximately 500 family-run companies produce vegetables in an area of 250 hectares, each employing up to $>100$ workers. Tomatoes and cucumbers account for $80 \%$ of the 100 million kilos of annual total production volume. Another reason that greenhouse production is a trending topic is that in recent years, new forms of indoor plant production have emerged, including small-scale private greenhouses, urban roof cultivation [1] and the cultivation of medicinal cannabis [2]. Rather than chemical plant protection products, biological agents are now almost exclusively used for protecting tomato and cucumber plants. These include various pest control organisms (mites, insects and nematodes) and beneficial bacteria and fungi.

Vegetable production is concentrated in certain areas of Finland, a large cluster being in the Swedish-speaking area in the western part of the country. Most greenhouse workers are regular employees, but $>60 \%$ have an immigrant

Address for correspondence: Katri Suuronen, Finnish Institute of Occupational Health, Topeliuksenkatu 41 B, 00250, Helsinki, Finland

E-mail: katri.suuronen@ttl.fi

Received: 13.12.2021; accepted: 15.02.2022; first published:02.03.2022 background. These are mostly from Thailand, Vietnam, the Balkan area, and Ukraine. The lack of a common language and the different cultural backgrounds of the workers may hamper work safety and hygiene, as well as the workers' access to occupational health and social care, which are the principal rights of all employees.

Recent Danish studies have reported occupational hygiene measurements in greenhouses that use biological pest control. These studies have covered, for example, dusts, microbial impurities and endotoxins in decorative flower [3] and vegetable production [4-7].

Greenhouse workers may suffer from occupational allergic diseases, such as asthma, rhinitis, conjunctivitis and contact urticaria, caused by IgE-mediated allergy to the proteins of production plants $[8,9]$ or the proteins of beneficial mites or insects [10]. Cross-sectional studies in Sweden [11], Denmark [12] and The Netherlands [13] have discovered sensitisation to pest control mites in $20-30 \%$ of greenhouse workers, and a recent Finnish study by the authors discovered as high as $50 \%$ prevalence of allergy to pest organisms including mites and insects [14]. However, it is probable that not all cases were included, as there were also seasonal or short-term workers. They may finish their work and return to their home countries if they become symptomatic. While plants and micro-organisms seem to cause IgE-mediated sensitisation and occupational diseases among this workforce, other exposures such as dust, endotoxins, bacteria and fungi play a role in general working conditions and may affect respiratory health [15]. 
In Finland in the 2000s, solitary occupational allergic diseases have been diagnosed among greenhouse workers [10], confirmed by unpublished data from the Finnish Institute of Occupational Health (FIOH). It is suspected that these cases represent only a minority of workers with these diseases, and that IgE-mediated sensitisation may be common among this workforce. Therefore, between 2018 2020 , a survey was carried out in eight tomato and cucumber greenhouse companies that use biological pest control.

\section{OBJECTIVE}

The aim was to study sensitisation and allergic symptoms among the greenhouse workers and to promote their health and work ability through early identification, improved diagnostics, better working habits, and exposure control. The study comprised 1) a cross-sectional clinical survey of about 120 workers in eight greenhouses, 2) an assessment of exposure to organic dust, endotoxins, bacteria and fungi during greenhouse work through air measurements and observing the work, and 3) an analysis of FIOH's clinical patient data on greenhouse workers during the 2000s. The clinical findings have been reported recently $[14,16,17]$ and the current article presents the results of the exposure assessments.

\section{MATERIALS AND METHOD}

Workplaces. The study was conducted in eight companies that grow tomatoes and/or cucumber in a rockwool or sod medium, in connection with a cross-sectional clinical study. Six companies were recruited via a local producer organisation, two were found on the internet and contacted directly. The assessments were conducted in seven workplaces (A-G) on one day between January - April 2019. One workplace (company $\mathrm{H}$ ) was recruited later than the others and thus was not visited until October 2020, during partial dismantling of growth. Most companies had several greenhouses at varying stages of production. On the morning of the assessment visit, the greenhouses were inspected and one to two were selected for exposure assessments: those with the greatest production volume or the 'main greenhouse', or those with the most working activities at the time of the visit.

Information on conditions. By interviewing the foreman or owner of the greenhouse, or through observation, the following background information was collected in a structured form: 1) total number of employees in the company, 2) production plant, 3) growing area in each greenhouse, 4) observed pests, 5) use of biological pest control organisms, 6) use of chemical pesticides, 7) upkeep of chemical inventory, 8 ) working activities in the observed greenhouses during the visit, and 9) work clothing and personal protective equipment (PPE) (Tab. 1).

Sampling strategy. One to three employees per company who were known to work in the active-stage greenhouses were randomly selected and gave their informed consent to carry sampling equipment. One to three breathing zone samples of dust (inhalable and respirable), viable microbes (bacteria and fungi) and endotoxins were collected per greenhouse to assess the workers' exposure. A total of 23 personal samples per impurity were gathered: 16 from the tomato and seven from the cucumber greenhouses. One stationary sample of dust, microbes and endotoxins was also collected in each company to evaluate the general ambient air concentrations during normal greenhouse duties and daily tasks (Tab. 1). An additional stationary air sample of microbes was collected directly by an impactor to culture media, which enabled better identification of the fungi families and species in each greenhouse.

Sampling time was 4-5 hours, except in one personal measurement where it was only 1.5 hours due to changes in work arrangements, and in the stationary six-phase impactor samples where it was 3-15 minutes. Ambient air temperature and relative humidity were followed on the companies' own monitors, or if these were not available, on a direct-reading TSI Q-Trak 7565 indoor air quality monitor. With the exception of company $\mathrm{H}$, the measurements were carried out during the winter season when the ground was frozen and covered with snow.

Dust. Inhalable $\left(\mathrm{D}_{50} 100 \mu \mathrm{m}\right)$ and respirable $\left(\mathrm{D}_{50} 4 \mu \mathrm{m}\right)$ fractions of dust were collected on Millipore-filter $(\varnothing 25 \mathrm{~mm}$ AAWP, pore size $0.8 \mathrm{~mm}$, Merck Millipore) and Multidust Foam disc (SKC), respectively, using an IOM sampler (SKC) and a pre-calibrated Gilian 5000 pump, at a flow rate of 2.0 $\mathrm{L} / \mathrm{min}$. Dust samples were analysed gravimetrically. Results that were below the limit of detection (LOD) were set to $50 \%$ of LOD, which was $0.06 \mathrm{mg}$ per sample for both fractions.

Viable microbes. Mesophilic, airborne viable bacteria and fungi were collected in open face cassettes (Millipore Aerosol Analysis Monitor MAWP 037 AO, Merck Millipore) with sterilised polycarbonate filters (Nuclepore 110807, $0.4 \mathrm{~mm}, \varnothing 37 \mathrm{~mm}$, Whatman International Ltd.) at a flow rate of $2 \mathrm{~L} / \mathrm{min}$ using a pre-calibrated Gilian 5000 sample pump (Sensidyne). All samples were kept at refrigerator temperature, and reached the laboratory within 48 hours of sampling. The filters were diluted in $6.5 \mathrm{ml}$ of autoclaved extraction solution containing $1 \mathrm{~g}$ of peptone and $0.1 \mathrm{ml}$ Tween 80 per $1 \mathrm{~L}$ of distilled water, shaken for 15 minutes, and the liquid removed to a test tube for dilutions for cultivation. The viable bacteria and fungi of the samples were cultivated for 7 days at $+25^{\circ} \mathrm{C}$ as follows: mesophilic actinobacteria (e.g. Streptomyces spp.) and other bacteria on tryptone yeast extract glucose (THG) -agar, and mesophilic fungi on media with Rose Bengal (Hagem)-agar and dichloran $18 \%$ glycerol (DG-18) -agar. After the incubation period, the colonies were counted and identified, actinobacteria and fungi by microscopic examination of morphology. Concentrations of viable micro-organisms are expressed as $\mathrm{cfu} / \mathrm{m}^{3}$. The LOD of cultivation methods was $1 \mathrm{cfu} / \mathrm{m}^{3}$.

Additional stationary air samples were collected for better identification of genera using a six-phase impactor (10-800, Andersen Inc., Georgia, USA) and a pre-calibrated sampling pump (Busch SV1008A) at an airflow of $28.3 \mathrm{~L} / \mathrm{min}$, the LOD was $1 \mathrm{cfu} / \mathrm{m}^{3}$. The samples were aseptically handled, packed in a way that they remained at the preferred temperature of $+4-+8^{\circ} \mathrm{C}$, and delivered to the laboratory within 24 hours of sampling. The plates were incubated in the same way as the filter samples. The colonies were counted, and genera or species recognized with a light microscope. Concentration was the sum of all colonies of the 6 phases [18]. 
Endotoxins. Inhalable endotoxins were collected onto a glass fibre filter $(1.0 \mathrm{~mm}, \varnothing 25 \mathrm{~mm}$, SKC Inc.) by an IOM Sampler at a flow rate of $2 \mathrm{~L} / \mathrm{min}$ using a pre-calibrated Gilian 5000 sample pump (Sensidyne). The biologicallyactive endotoxins were measured using a validated kinetic chromogenic Limulus amoebocyte lysate assay (Kinetic QCL, Lonza). The results are expressed as endotoxin units per cubic metre of air $\left(\mathrm{EU} / \mathrm{m}^{3}\right)$. The LOD of the analysis is $0.005 \mathrm{EU} / \mathrm{ml}$.

FIOH's laboratory services are accredited in accordance with EN ISO/IEC 17025, as are the sampling and analysis of inhalable and respirable dust and endotoxins, and the analyses of filter and impactor samples (bacteria and fungi).

Statistical analysis. SPSS Statistics 27.0 Was used for the data analysis. The levels of inhalable dust and microbes in the tomato and cucumber greenhouses were compared using the independent samples Mann-Whitney U-test. A p-value of $<0.05$ was considered statistically significant.

\section{RESULTS}

Table 1 presents the details and conditions of the assessed greenhouses. All the participating companies produced all year round, therefore there were no significant seasonal changes in work tasks or practices. It was concluded that in companies A-G the outdoor biological activity was insignificant due to the cold season; hence, outdoor microbe samples were taken only in company $\mathrm{H}$. The total number of workers during the visit was 11-32, who worked in one or more greenhouses during the day, some of them in the assessed houses (including those with personal sampling) and some in adjacent houses. The active production phase was observed and measured in which the plants both grow and produce fruit, thus needing constant attention from the workers. This is the most labour- and exposure-intensive phase involving most of the working time. The workers performed multiple tasks during the measurements, typical tasks were removing side growth

Table 1. Details and conditions in 8 Finnish greenhouse companies (A-H), based on interviews and observations in 2019 and 2020 ; conducted air measurements. Some companies had 2 observed greenhouses

\begin{tabular}{|c|c|c|c|c|c|c|c|c|c|c|c|c|}
\hline 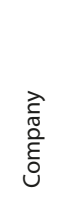 & 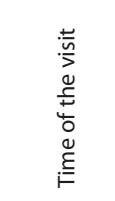 & 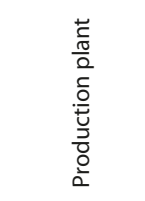 & 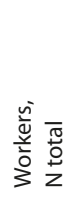 & 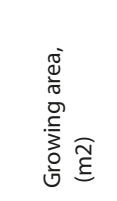 & 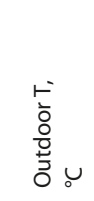 & 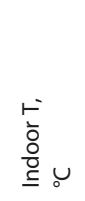 & 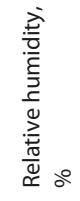 & 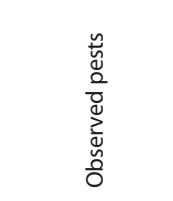 & 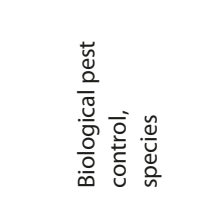 & 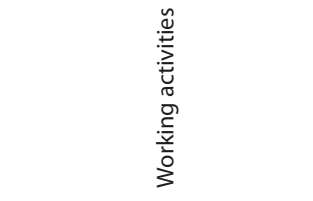 & 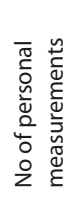 & 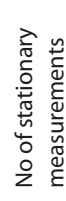 \\
\hline A & March & Tomato & 11 & 1,6800 & $-1-+5$ & NA & $60-80$ & NA & $\begin{array}{c}\text { Macrolophus. } \\
\text { pygmaeus }\end{array}$ & Removing leaves & 3 & 1 \\
\hline B-1 & January & Tomato & 12 & 4,060 & -7 & 24 & $60-85$ & Whitefly & $\begin{array}{c}\text { Macrolophus } \\
\text { pygmaeus }\end{array}$ & Picking tomatoes & 2 & 1 \\
\hline B-2 & January & Tomato & 12 & 1,518 & -7 & 24 & $65-85$ & Whitefly & $\begin{array}{l}\text { Enermix } \\
\text { Macrolophus } \\
\text { pygmaeus }\end{array}$ & Picking tomatoes & 1 & 0 \\
\hline$C-1$ & January & Tomato & 12 & 11,000 & -7 & 24 & $70-80$ & Whitefly & $\begin{array}{c}\text { Macrolophus } \\
\text { pygmaeus, Encarcia } \\
\text { formosa }\end{array}$ & $\begin{array}{l}\text { Picking tomatoes, pollening, } \\
\text { removing side growth }\end{array}$ & 2 & 1 \\
\hline D & March & Cucumber & 15 & 2,000 & +4 & 26 & 72 & Whitefly, Thrip & Amblyseius swirskii & $\begin{array}{l}\text { Picking cucumber, removing } \\
\text { leaves, stringing tops }\end{array}$ & 2 & 1 \\
\hline E-1 & February & Tomato & 11 & 5,600 & $<0 \mathrm{~b}$ & 22 & $70-75$ & Whitefly & Encarcia formosa & $\begin{array}{l}\text { Removing leaves and } \\
\text { cleaning the aisles }\end{array}$ & 2 & 1 \\
\hline $\mathrm{E}-2$ & February & Tomato & 11 & 4,715 & $<0 \mathrm{~b}$ & $22-23$ & NA & Whitefly & $\begin{array}{c}\text { Macrolophus } \\
\text { pygmaeus, Encarcia } \\
\text { formosa }\end{array}$ & $\begin{array}{l}\text { Removing leaves, picking } \\
\text { tomatoes }\end{array}$ & 1 & 0 \\
\hline $\mathrm{F}-1$ & March & $\begin{array}{c}\text { Tomato, } 2 \\
\text { greenhouses }\end{array}$ & 32 & $\begin{array}{c}15,000 \\
\text { and } 2,200\end{array}$ & -3 & 22 & NA & Whitefly, Spint & $\begin{array}{c}\text { Macrolophus } \\
\text { caliginosus, } \\
\text { Enermixa, } \\
\text { Phytoseiulus } \\
\text { persimilis }\end{array}$ & $\begin{array}{l}\text { Picking tomatoes, removing } \\
\text { side growth }\end{array}$ & 2 & 1 \\
\hline G-1 & February & Tomato & 12 & 1,000 & $-1-+3$ & 23,5 & NA & Whitefly, Spint & $\begin{array}{c}\text { Encarcia formosa, } \\
\text { Macrolophus } \\
\text { pygmaeus }\end{array}$ & $\begin{array}{l}\text { Removing leaves and side } \\
\text { growth }\end{array}$ & 2 & 1 \\
\hline G-2 & February & Cucumber & 12 & 4,386 & $-1-+3$ & 24 & NA & $\begin{array}{l}\text { Whitefly, Thrip, } \\
\text { Spint }\end{array}$ & NA & $\begin{array}{l}\text { Picking cucumber, taking off } \\
\text { sprouse }\end{array}$ & 1 & 0 \\
\hline $\mathrm{H}$ & October & Cucumber & 16 & 10,000 & $+12-16$ & NA & NA & NA & NA & $\begin{array}{l}\text { Renewal of } 1 / 4 \text { of the } \\
\text { growth, cleaning leaf debris } \\
\text { from the floor, removal of } \\
\text { top leaves }\end{array}$ & 3 & $1^{\mathrm{c}}$ \\
\hline
\end{tabular}

${ }^{\mathrm{a}}$ Enermix is a mixture of 2 beneficial parasitic wasps: Encarcia formosa and Eretmocerus eremicus; ${ }^{\mathrm{b}}$ Not measured, but freezing; ${ }^{\mathrm{c}}$ Temperature $>0$; outdoor microbes measured in addition. 
and old leaves by stripping and cutting, stringing the plant tops and picking (harvesting) tomatoes or cucumbers. The workers were told to work as usual during the measurement.

All companies had earlier observations of harmful organisms, and beneficial micro-organisms, such as mites or predatory bugs, were used as the primary measure to control pests. In all the observed greenhouses, control organisms were added on a regular basis and had been added recently, that is, one week-two months prior to the inspection visit. All of them had also occasionally used chemical or biological fungicides, and most had up-to-date listings of chemical and biocidal products. The most common clothing for the workers was a t-shirt and shorts or trousers, leaving open skin areas, especially the arms, susceptible to contact with plants. About half of the observed workers wore short-stalked disposable gloves, most had repeated contact with plants, and none used respiratory protection. It was observed that all the greenhouses except one were tidy and well organised; they had a clean general appearance and there was very little visible dust on surfaces or in the air. The greenhouses of this study used all table-top growing media which contained no soil. The concrete floors were covered with canvas, and as the removed leaves had to be cleaned away regularly, the floors also stayed tidy. This was typical for the companies at all times, and none of them had cleaned the premises specifically before our visit. All of the companies stated that they cleaned and washed the greenhouses thoroughly 1-2 times/year, when the entire growth was renewed. All the greenhouses also had certified quality systems, which require high level of cleanliness.

Personal dust measurements $(\mathrm{N}=23)$ revealed the median of inhalable dust in the breathing zone of the workers to be $0.24 \mathrm{mg} / \mathrm{m}^{3}$ (mean 0.45; range 0.08-2.5). The highest level of $2.5 \mathrm{mg} / \mathrm{m}^{3}$ was discovered from a worker in greenhouse E-1 who, for some time during the measurement, removed leaves, cleaned aisles and packed leaf waste into an open container above shoulder level in tomato. The lowest level

Table 2. Viable microbes in 8 stationary measurements in Finnish greenhouses $\left(\mathrm{cfu} / \mathrm{m}^{3}\right)$. Stationary samples were collected by 2 methods: directly on growing media with impactor and on filter. The microbes were determined in 3 different growing media to identify various genera. Median, mean and range are calculated from samples with $>0$ result

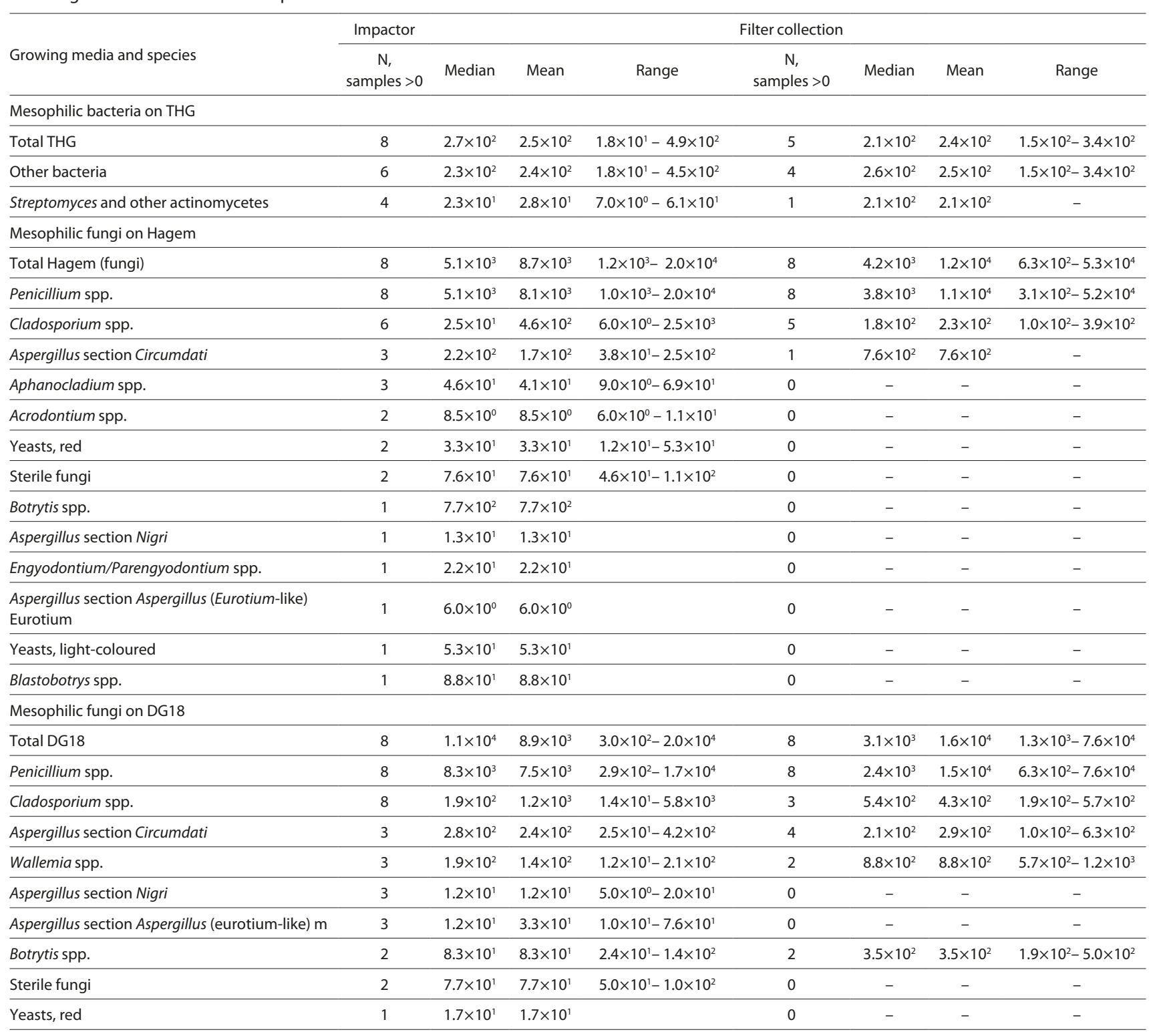


was found in tomato-picking in greenhouse B-1. The median of inhalable dust was $0.21 \mathrm{mg} / \mathrm{m}^{3}$ in the tomato houses and $0.62 \mathrm{mg} / \mathrm{m}^{3}$ in the cucumber houses; the difference between them was statistically significant $(\mathrm{p}=0.01)$. All the respirable dust concentrations were below the LOD, except in 2 samples $\left(0.68 \mathrm{mg} / \mathrm{m}^{3}\right.$ and $\left.0.31 \mathrm{mg} / \mathrm{m}^{3}\right)$ which also had the highest inhalable dust concentrations. In 8 stationary samples, the median concentration of inhalable dust was $0.09 \mathrm{mg} / \mathrm{m}^{3}$ (mean 0.09; range 0.08-0.12), and respirable dust was below the LOD in all of them.

Table 2 presents stationary measurements of microbes based on 2 different methods. Total median amounts of microbes on impactor $\left(2.7 \times 10^{2} \mathrm{cfu} / \mathrm{m}^{3}\right.$ in THG; $5.1 \times 10^{3}$ $\mathrm{cfu} / \mathrm{m}^{3}$ in Hagem; and $1.1 \times 10^{4} \mathrm{cfu} / \mathrm{m}^{3}$ in $\left.\mathrm{DG}-18\right)$ and on filter $\left(2.1 \times 10^{2} \mathrm{cfu} / \mathrm{m}^{3}\right.$ in THG; $4.2 \times 10^{3} \mathrm{cfu} / \mathrm{m}^{3}$ in Hagem; and $3.1 \times 10^{3} \mathrm{cfu} / \mathrm{m}^{3}$ in DG-18) were quite comparable, but more species could be identified by the impactor method. The most commonly identified and also most abundantly found families or species by both impactor and filter method were the Penicillium and Cladosporium families and Aspergillus section Circumdati.

Personal exposure (23 samples, Tab. 3) to microbes exceeded the stationary measurements by about 10 times, the most common species being the same in each case. The mean levels of microbes in tomato and cucumber houses were $2.7 \times 10^{3}$ and $1.6 \times 10^{4}$ on THG; $3.6 \times 10^{5}$ and $1.7 \times 10^{5}$ on
Hagem; and $8.1 \times 10^{5}$ and $1.9 \times 10^{5}$ on DG-18, respectively. The differences were not statistically significant.

Airborne endotoxins above the LOD were found in 5 of the 23 personal samples at concentrations of 4.2-9.8 EU/m3. All stationary samples were below the LOD. Four samples taken from the growth media contained 60-300 EU/mg, and 4 of the 11 plant leaf samples contained endotoxins (65-750 $\mathrm{EU} / \mathrm{mg})$.

\section{DISCUSSION}

The observations of the working methods and the results of measurements of inhalable dust and microbial impurities in 8 Finnish vegetable greenhouses are presented. The assessments were conducted during normal working days and the performance of various tasks in greenhouses with tomato and/or cucumber plants in fruit production phase. The processes and work tasks in the observed greenhouses were quite similar. Overall, the greenhouses seemed to function in a well-organised and efficient manner, and the cleanliness of the facilities was striking in almost all the companies. This study represents a relatively small assessment, conducted in parallel with a cross-sectional medical study, but still presents insights into the occupational hygiene of year-round greenhouse work in a cold climate.

Table 3. Viable bacteria and fungi in 23 personal samples in eight Finnish tomato and cucumber greenhouses (cfu/ $\left.\mathrm{m}^{3}\right)$; the microbes were determined in three different growing media to identify various genera. Median, mean and range are calculated from samples with $>0$ result

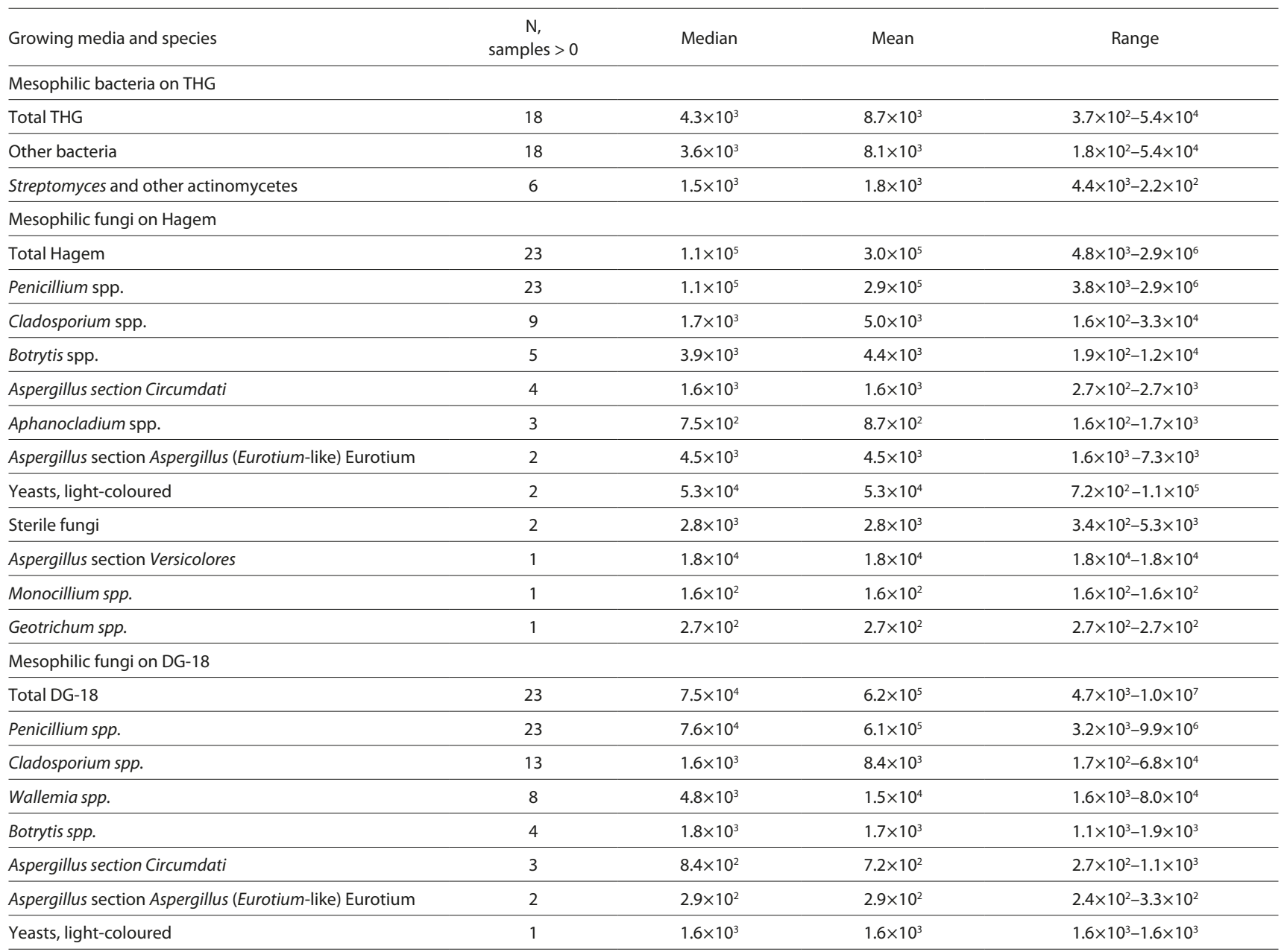


As expected, based on observations, the median level of inhalable dust in the breathing zone was low, about $1 / 10$ of the Finnish OEL for organic dust, which is $5 \mathrm{mg} / \mathrm{m}^{3}$. Three larger Danish studies discovered higher personal exposure to dust, the medians being $0.042-3.22 \mathrm{mg} / \mathrm{m}^{3}$ [7] and as high as $7-15 \mathrm{mg} / \mathrm{m}^{3}$ in the dismantling of dry cucumber plants [6]. A median of $0.1-4.00 \mathrm{mg} / \mathrm{m}^{3}$ in tomato and $1.07-5.0 \mathrm{mg} / \mathrm{m}^{3}$ in cucumber houses has been discovered previously [5]. The present study also found some differences between the tomato and cucumber houses; the median level of dust was higher in the cucumber houses. However, the single highest dust concentration was discovered in a generally clean-looking tomato house where, among other tasks, the observed worker collected leaf waste from aisles into baskets which he then lifted into a container above shoulder height. It is possible that the dust level in the lifting phase was higher than the measured mean of $2.5 \mathrm{mg} / \mathrm{m}^{3}$. Based on this finding, it seems advisable to find other ways to handle the leaf waste, for example, pulling it along the floor directly to a container or tarpaulin on floor level. Dust levels were clearly lower in the stationary samples that represented ambient air, and were located at varying distances from the dust-producing tasks.

Greenhouse dust, despite its low-to-moderate level, may contain biologically active particles such as allergenic proteins of pests, pest control organisms and plants (e.g. pollen), as well as microbes and their metabolites. It is thus advisable to aim for the lowest dust levels possible. Respiratory and skin sensitisation is known to occur in greenhouses and is due to allergenic protein impurities, but to our knowledge, exposure to plant and animal allergens has not been studied in related surroundings. It would be interesting to examine specifically airborne proteins in greenhouses, which would need special methodology.

The microbial impurities reflected typical species in Finland and elsewhere in the northern hemisphere. Their levels were relatively comparable to the levels reported in Danish greenhouses $[4,6]$ and generally lower than those reported from other sectors of farming in Finland (unpublished measurement register of FIOH). In addition to dust, Madsen et al. [6] also reported the highest levels of fungi and bacteria in the dismantling of dry cucumber growth, which caused about 10 times the microbial exposure caused by dismantling moist growth. In the present study, personal exposure to microbes, similar to dust, clearly exceeded the stationary levels. The highest concentration of microbes was discovered in the person who was also the most exposed to dust when engaged in lifting piles of leaf debris above shoulder height. This high exposure to microbes further underlines the need to improve the methods for performing this task. Exposure to endotoxins was low in comparison to many other sectors of agriculture or bio-economy [19], and according to an unpublished measurement register of the $\mathrm{FIOH}$, which, considering the cleanliness of the greenhouse environment, was to be expected. It was also lower than in Danish greenhouses [5]. The authors of the present article, however, are not familiar with the general working environment in Danish greenhouses in related activities, and do not know the reason for that finding.

Although microbial impurities rarely induce IgE-mediated allergy, they have caused other health problems such as organic dust toxic syndrome (ODTS), allergic alveolitis (also called hypersensitivity pneumonitis), respiratory irritation, and changes in lung function in sectors with heavy exposure
[15]. Little is known about the dose-effect relationship of these, but exposure thresholds for some diseases or symptoms have been suggested earlier for highly exposed populations, such as farmers, saw-mill workers and waste handlers. For example, the lowest observed effect levels (LOEL) of $1-2 \times 10^{5}$ fungal spores $/ \mathrm{m}^{3}$ were found for nasal, eye and throat symptoms, and lung function changes [20, 21]. In farmers, a LOEL of $3 \times 10^{6}$ spores $/ \mathrm{m}^{3}$ has been suggested for coughing [20]. Fever attacks have appeared at levels of $2 \times 10^{9}$ spores $/ \mathrm{m}^{3}$ in farmers with ODTS and at about $1-4 \times 10^{8}$ spores $/ \mathrm{m}^{3}$ in individuals with hypersensitivity pneumonitis [22]. Fungal spores cannot be directly compared with the presented results, but they have been reported to exceed cfu's 2.5-4 -fold in related surroundings [6]. The presented median results of about $10^{3}-10^{4} \mathrm{cfu} / \mathrm{m}^{3}$ of fungi were below all these estimated threshold levels. However, microbe-related health problems cannot be ruled out in this work as airborne microbes may vary, and some solitary high concentrations were also observed.

Most of the time the workers performed several different tasks during workdays. As the authors did not want to interfere with the normal routines and wanted to achieve a realistic understanding of the exposures, it was not possible to concentrate separately on single tasks. This made it difficult to compare tasks but it does give a general view of the exposures. This was also the case with the dismantling of cucumber growth, which has previously been identified as a highexposure task [5]. It is suspected that heavier exposure occurs during dismantling in the studied companies, and one visit at a time was arranged when such work was being carried out. However, in the cucumber house assessed, the dismantling was part of other daily tasks, and the whole process seemed orderly, the plants were still relatively fresh, and removed tidily by the workers. Based on the measurements, this process produced only a small quantity of impurities.

In order to prevent allergic respiratory diseases, work practices are recommend that do not include lifting leaf debris. Instead, sweeping it on the floor is recommended, or collecting it directly onto canvases that can be folded. Rolling dismantling of relatively fresh plants also produced only a little dust. According to the commonly accepted hierarchy of hazard controls, altering working methods and improving hygienic procedures comes first. It is considered that respiratory protection is only required in specific cases, for example, FFP2-type filter masks should be used in work phases with high levels of dust. To avoid skin exposure and sensitisation, long-sleeved shirts or arm covers and high collars, in addition to gloves are recommended. Changing clothes and taking a shower immediately after work are also recommend to avoid extended exposure to allergens. Employers are encouraged to make the washing of work clothes possible at the workplace.

Communication is challenging as in many cases the workers have no common language with the entrepreneurs responsible for safety in these companies. Cultural differences are also sometimes a problem. It may, therefore, be difficult to broach health matters with employees. To improve communication, the authors have produced written instructions for employers and occupational health services, which address allergy risks as well as communication problems. For the workers, the authors have produced a non-verbal, animated short film summarising the findings or the study, and giving advice. The film is freely available and is published on Youtube [23]. 


\section{CONCLUSIONS}

In conclusion, low to moderate levels of dust and microbes, and diminutive exposure to endotoxins were found in the surveyed Finnish tomato and cucumber greenhouses. With the exception of microbes, the levels were lower than those seen in other recent studies. Plant and micro-organism allergens are significant exposures in vegetable greenhouses, but their assessment requires special methodology. The work seemed to be well organised and tidy, but some risk phases for respiratory exposure were identified, and little attention had been paid to skin exposure and its prevention. Implementing preventive measures among a workforce with poor language comprehension and varying cultural backgrounds will require special efforts.

\section{Acknowledgements}

The authors warmly thank the greenhouse companies and their employees for their participation in the study. Financial support was gratefully received from the Finnish Work Environment Fund.

\section{REFERENCES}

1. Ercilla-Montserrat M, Izquierdo R, et al. Building-integrated agriculture: A first assessment of aerobiological air quality in rooftop greenhouses (i-RTGs). Sci Total Environ. 2017; 598: 109-20. doi:10.1016/j.scitotenv.2017.04.099

2. Couch JR, Grimes GR, Green BJ, et al. Review of NIOSH CannabisRelated Health Hazard Evaluations and Research. Ann Work Expo Health. 2020; 64(7): 693-704. doi:10.1093/annweh/wxaa013

3. Thilsing T, Madsen AM, Basinas I, et al. Dust, endotoxin, fungi, and bacteria exposure as determined by work task, season, and type of plant in a flower greenhouse. Ann Occup Hyg. 2015; 59(2): 142-57. doi:10.1093/annhyg/meu090

4. Hansen VM, Meyling NV, Winding A, et al. Factors affecting vegetable growers' exposure to fungal bioaerosols and airborne dust. Ann Occup Hyg. 2012; 56(2): 170-81. doi:10.1093/annhyg/mer090

5. Madsen AM, Hansen VM, Nielsen SH, et al. Exposure to dust and endotoxin of employees in cucumber and tomato nurseries. Ann Occup Hyg. 2009; 53(2): 129-38. doi:10.1093/annhyg/men073

6. Madsen AM, Tendal K, Frederiksen MW. Attempts to reduce exposure to fungi, $\beta$-glucan, bacteria, endotoxin and dust in vegetable greenhouses and a packaging unit. Sci Total Environ. 2014; 468-469: 1112-21. doi:10.1016/j.scitotenv.2013.09.014

7. Madsen AM, Thilsing T, Bælum J, et al. Occupational exposure levels of bioaerosol components are associated with serum levels of the acute phase protein Serum Amyloid A in greenhouse workers. Environmental health: a global access science source. 2016; 15: 9. doi:10.1186/s12940016-0090-7

8. Koistinen T, Ruoppi P, Putus T, et al. Occupational sensitization to storage mites in the personnel of a water-damaged grocery store. Int Arch Occup Environ Health. 2006; 79(7): 602-6. doi:10.1007/s00420006-0097-4

9. Vandenplas O, Sohy C, D'Alpaos V, et al. Tomato-induced occupational asthma in a greenhouse worker. J Allergy Clin Immunol. 2008; 122(6): 1229-31. doi:10.1016/j.jaci.2008.07.035

10. Lindström I, Karvonen H, Suuronen K, et al. Occupational asthma from biological pest control in greenhouses. J Allergy Clin Immunol Pract. 2018; 6(2): 692-4.e3. doi:10.1016/j.jaip.2017.08.034

11. Kronqvist M, Johansson E, Kolmodin-Hedman B, et al. IgEsensitization to predatory mites and respiratory symptoms in Swedish greenhouse workers. Allergy. 2005; 60(4): 521-6. doi:10.111 $1 /$ j.1398-9995.2004.00687

12. Bælum J, Birkhøj Kærstad M, Enkegaard A, et al. Health effects of predatory beneficial mites and wasps in greenhouses. Research report. Danish Environmental Protection Agency, Odense, Denmark, 2007.

13. Groenewoud GC, de Graaf in 't Veld C, Van Oorschot-van Nes AJ, et al. Prevalence of sensitization to the predatory mite Amblyseius cucumeris as a new occupational allergen in horticulture. Allergy. 2002; 57(7): 614-9. doi:10.1034/j.1398-9995.2002.203511

14. Suojalehto H, Hölttä P, Suomela S, et al. High Prevalence of Sensitization to Mites and Insects in Greenhouses Using Biologic Pest Control. J Allergy Clin Immunol Pract. 2021. doi:10.1016/j.jaip.2021.07.014

15. Eduard W. Fungal spores: a critical review of the toxicological and epidemiological evidence as a basis for occupational exposure limit setting. Crit Rev Toxicol. 2009; 39(10): 799-864. doi:10.3109/10408440903307333

16. Lindstrom I, Hölttä P, Suuronen K, et al. High prevalence of sensitization to bumblebee venom among greenhouse workers. J Allergy Clin Immunol Pract. 2021. doi:10.1016/j.jaip.2021.09.025

17. Suojalehto H, Hölttä P, Lindstrom I, et al. Prevalence of tomato and cucumber sensitization among greenhouse workers. J Allergy Clin Immunol Pract. 2021. doi:10.1016/j.jaip.2021.09.038

18. Andersen A. New sampler for the collection, sizing, and enumeration of viable airborne particles. J Bacteriol. 1958; 76(5): 471-84. doi:10.1128/ jb.76.5.471-484.1958

19. Liebers V, Bruning T, Raulf M. Occupational endotoxin exposure and health effects. Arch Toxicol. 2020; 94(11): 3629-44. doi:10.1007/ s00204-020-02905-0

20. Eduard W, Douwes J, Mehl R, et al. Short term exposure to airborne microbial agents during farm work: exposure-response relations with eye and respiratory symptoms. Occup Environ Med. 2001; 58(2): 113-8. doi:10.1136/oem.58.2.113

21. Heldal KK, Eduard W. Associations between acute symptoms and bioaerosol exposure during the collection of household waste. Am J Ind Med. 2004; 46(3): 253-60. doi:10.1002/ajim.20058

22. Malmberg P, Rask-Andersen A, Rosenhall L. Exposure to microorganisms associated with allergic alveolitis and febrile reactions to mold dust in farmers. Chest. 1993; 103(4): 1202-9. doi:10.1378/ chest.103.4.1202

23. Suuronen K, Koponen M, Hölttä $\mathrm{P}$, et al. Working in a greenhouse. https://www.youtube.com/watch? $\mathrm{v}=\mathrm{hKH}$ G GcfMBMs\&t=2s: (access 2021.12.10) 